Esta publicación cientifica en formato digital es continuidad de la revista impresa ISSN-Versión Impresa 0798-1406 / ISSN-Versión on line 2542-3185Depósito legal pp
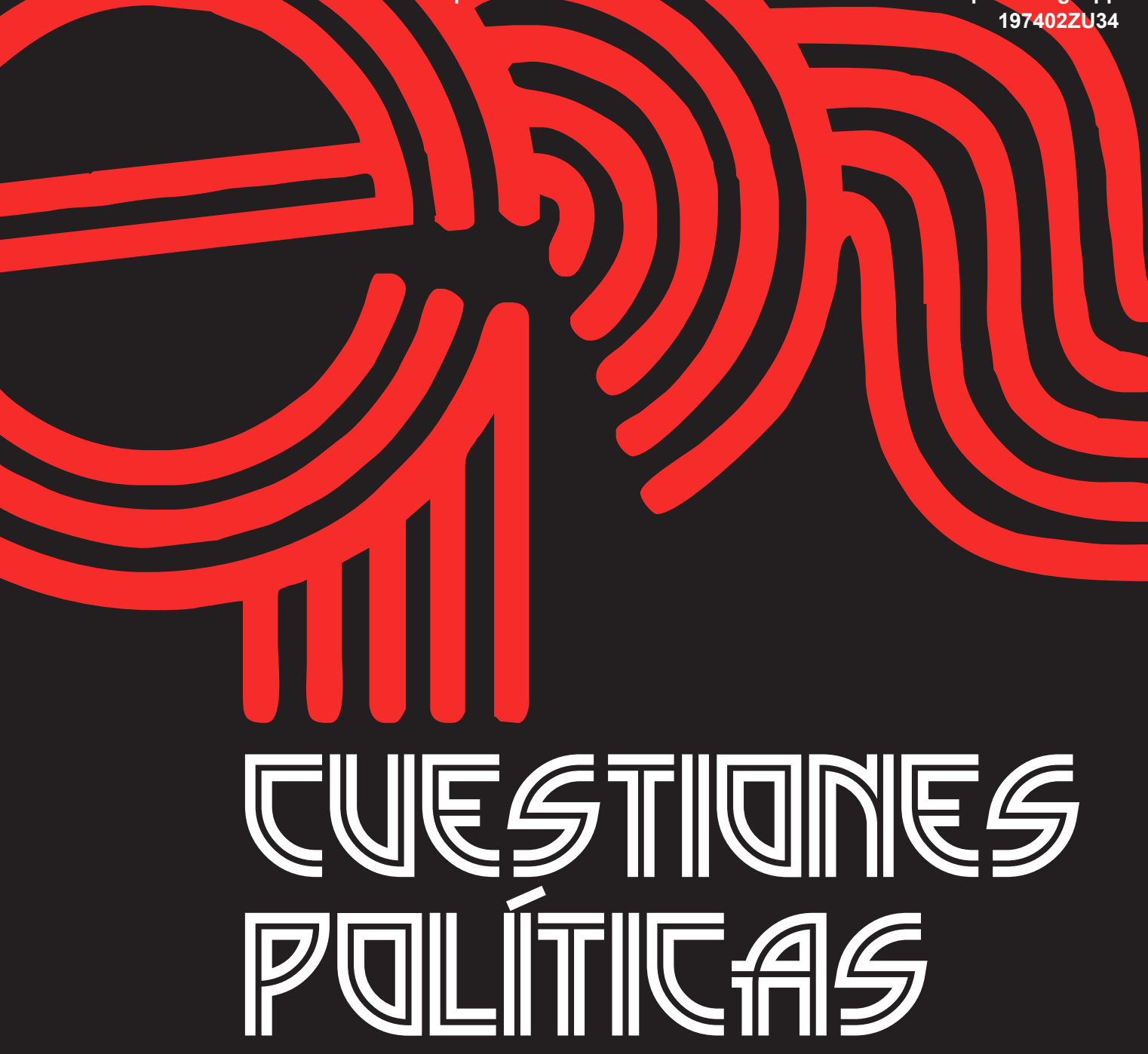

Instituto de Estudios Políticos y Derecho Público "Dr. Humberto J. La Roche" de la Facultad de Ciencias Jurídicas y Políticas de la Universidad del Zulia Maracaibo, Venezuela
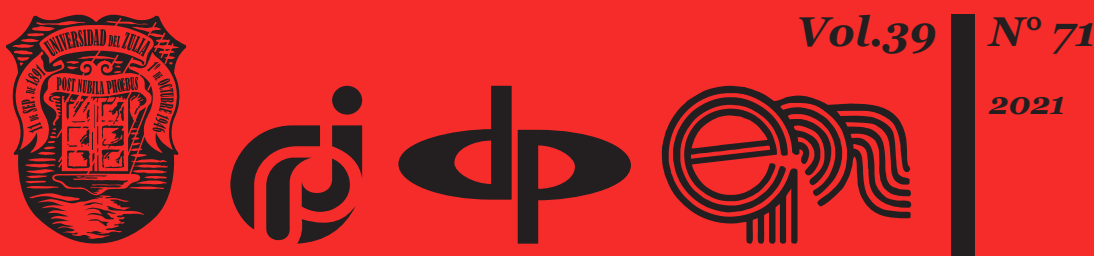


\title{
Historical overlook on the birth and formation of the institute of departmental procedural control in predictional criminal court proceedings in Russia
}

\author{
DOI: https://doi.org/10.46398/cuestpol.3971.32
}

\author{
Dmitriy A. Ivanov * \\ Kristina A. Moskovtseva ** \\ Olga V. Khimicheva *** \\ Vasily Dz. Potapov **** \\ Elmir N. Alimamedov *****
}

\section{Abstract}

The authors submit to a detailed analysis the historical milestones of the origin and formation of the institution of departmental procedural control in criminal proceedings in Russia. Taking the generally accepted classification as the basis for constructing a preliminary investigation and highlighting seven periods of the formation of the institution of departmental procedural control, the principles for establishing a particular institutional model of a concrete historical period are reflected. As the main method in the process of writing this article, the general systemic method of cognition was used, which made it possible to comprehensively consider and analyze the process of origin and formation of the institution of departmental procedural control in pretrial criminal proceedings in Russia. In addition, the authors argue that the institution of departmental procedural control of judicial control in the Russian Federation is quite young and its mechanisms need in-depth study. It is concluded that, through the analysis of statistical data, law enforcement practice, as well as the opinions and developments of scientists-processes, made it possible to identify the optimal ways to solve existing problems and directions for improving criminal procedure legislation.

* Moscow State Institute of International Relations (University) of the Ministry of Foreign Affairs of the Russian Federation (MGIMO-University), Moscow, Russia. ORCID ID: https://orcid.org/oooo-00022023-3771

** Moscow University of the Ministry of Internal Affairs of Russia named by V.Ya. Kikot, Moscow, Russia. ORCID ID: https://orcid.org/oooo-0003-0007-0351

*** K.G. Razumovsky Moscow State University of Technologies and Management, Moscow, Russia. ORCID ID: https://orcid.org/oooo-0003-2295-2064

**** Pitirim Sorokin Syktyvkar State University (SyktSU), Syktyvkar, Russia. ORCID ID: https://orcid. org/oooo-0002-3150-088X

***** Finance University under the Government of the Russian Federation, Department of Legal Regulation of Economic Activities, Moscow, Russia. ORCID ID: https://orcid.org/oooo-0003-2477-3166 
Keywords: criminal proceedings; procedural control; head of the investigative body; preliminary investigation; legalinstitutional history.

\section{Visión histórica sobre el nacimiento y la formación del instituto de control procesal departamental en los procedimientos judiciales penales de predicción en Rusia}

\section{Resumen}

Los autores someten a un análisis detallado los hitos históricos del origen y la formación de la institución de control procesal departamental en los procedimientos penales en Rusia. Tomando la clasificación generalmente aceptada como base para construir una investigación preliminar y destacando siete períodos de la formación de la institución de control procesal departamental, se reflejan los principios para establecer un modelo institucional particular de un período histórico concreto. Como método principal en el proceso de redacción de este artículo, se utilizaron el método sistémico general de cognición, que permitió considerar exhaustivamente y analizar el proceso de origen y formación de la institución de control procesal departamental en los procedimientos penales previos al juicio en Rusia. Además, los autores argumentan que la institución del control procesal departamental del control judicial en la Federación de Rusia es bastante joven y sus mecanismos necesitan un estudio profundo. Se concluye que, un análisis de los datos estadísticos, la práctica de aplicación de la ley, así como las opiniones y desarrollos de los científicos-procesalistas, permitieron identificar las formas óptimas de resolver los problemas existentes y las direcciones para mejorar la legislación procesal penal.

Palabras clave: proceso penal; control procesal; jefe del órgano de investigación; investigación preliminar; historia jurídico-institucional.

\section{Introduction}

The issues of organizing the preliminary investigation in the Russian Federation have not lost their relevance for many years. The attention of scientists and practitioners is drawn to the comprehension of the logic of its development. It is obvious that the formation of the Russian criminal process is directly related to the formation of the Russian state and is developing in parallel with it. 
Dmitriy A. Ivanov, Kristina A. Moskovtseva, Olga V. Khimicheva, Vasily Dz. Potapov y Elmir N. Alimamedov

556

Historical overlook on the birth and formation of the institute of departmental procedural control in predictional criminal court proceedings in Russia

\section{Materials and methods}

The method of a systematic approach made it possible to consider the mechanism of departmental procedural control over the procedural activity of an investigator at the stages of initiating a criminal and preliminary investigation, as well as to study the interaction of the head of an investigative body and an investigator at these stages of pre-trial criminal proceedings.

The historical and legal method made it possible to study the genesis and legal nature of departmental procedural control over the activities of an investigator in pre-trial criminal proceedings.

The use of methods of analysis and synthesis made it possible to identify existing problems in law enforcement practice on the implementation of departmental procedural control in the course of pre-trial proceedings in criminal cases.

The formal-logical method made it possible to analyze the procedural independence of the investigator in the course of pre-trial proceedings in criminal cases and put forward proposals for improving legislation in this area.

The use of the formal legal method made it possible to characterize the relationship between prosecutorial supervision, judicial control and departmental procedural control over the activities of an investigator in pre-trial criminal proceedings.

As a result of the application of this methodology, new knowledge was obtained about the mechanism of departmental procedural control over the procedural activities of an investigator in pre-trial proceedings in criminal cases, as well as trends in improving legislation in order to optimize the work of investigative units at the stages of initiation of a criminal case and preliminary investigation.

\section{Results analysis}

The study of archival data shows that some surviving and extant sources say that the state power of the period of Kievan Rus actively influenced the administration of justice, resolved judicial and procedural issues that were previously regulated by generic customs. Along with this, the court, as an organ of state power exercising not only judicial, but also administrative functions, existed in two forms: as a "court of the prince himself" and as a "court of judges appointed by the prince".

The judiciary of the period of Kievan Rus can be described as uncontrolled. The court itself was an active participant in the search process: 
it participated in the search for evidence, investigated the circumstances of the case. With such a combination of the functions of the prosecution, the resolution of the case on the merits and the search for evidence there can be no talk of monitoring the actions and decisions of the persons carrying out the proceedings. Moreover, all administrative and judicial functions were concentrated "in one hand" (Kolokolov, 2009).

The procedural legislation of Russia before the judicial reform of 1860 resembled an "incoherent" collection of Peter's decrees, the Code of Tsar Alexei Mikhailovich, various orders and regulations. For the first time in the history of Russia, in the Decree of June 8, 1960, "The Institution of Judicial Investigators", the separation of the investigation function and its assignment to special officials - forensic investigators - was fixed. This served as the historical starting point for the formation and development of the institution of preliminary investigation.

In the pre-reform period until 1860, one of the laws of the Code of Laws of the Russian Empire "On Criminal Proceedings" was in force in the field of criminal proceedings, which provided for two types of investigation: preliminary and formal. The preliminary investigation was aimed at establishing the fact of the crime, identifying the perpetrators, and the formal one envisaged the scope of all subsequent actions directed against the known guilty person in order to establish the degree of his guilt. Both types of investigation were carried out by the police.

The reform of 1860 was the predecessor of the Peasant Reform of 1861 and was developed in the context of work on the "bills" of the reform of 1861, during the discussion of which there was a clear need to reform the police and separate investigative functions from it (Tarasov, 2001).

In the course of further reforms and with the adoption of a number of laws dated November 20, 1864, "Establishment of Judicial Regulations", "Charter of Criminal Procedure", the powers of judicial investigators are expanded. According to the Charter, the investigator was obliged to inform with complete impartiality all circumstances incriminating and acquitting the accused. Art. 263 of the same Charter contains a provision that a forensic investigator must inform the prosecutor about any investigation that he initiated not on the basis of a police report or a complaint from a private prosecutor. Control over the activities of the investigator by the prosecutor and the court is actively developing.

It would seem that the legislator of that time very carefully approached the issue of organizing the judicial investigation bodies, paying great attention to the powers of investigators, trying as much as possible to preserve their procedural independence, and also delimited the limits of control by the prosecutor's office and the court. In contrast to this opinion, A. G. Mamontov speaks, believing that "despite the entire progressive 
complex of transformations, there are a number of significant shortcomings that do not allow the apparatus of the judicial investigation to fully function positively.

This fact is influenced, first of all, by the existing absence of a normative separation of formal and preliminary investigation, which, in turn, predicted the same lack of a clear separation between investigation and inquiry" (Mamontov, 1984, p. 86).

The investigator himself had to carry out not only a preliminary investigation, but also an inquiry, and often a search. Also, according to the Charter, the investigator could not start an investigation without information about the person who committed the crime.

V. P. Danevsky in his work "Our preliminary investigation, its shortcomings and reforms" expresses the idea that the preliminary investigation according to the Judicial Statutes of Emperor Alexander II is perhaps the weakest part of the criminal process (Danevsky, 1985, p. 3) and explains this by the fact that the judicial investigation was given an accusatory status, control by the prosecutor's office and the court, which, as a rule, led to the unlimited termination of criminal cases by judicial investigators.

Also, relying on statistical data and reviews of contemporary jurors from the Kursk province, Moscow, and Kharkov, he came to the conclusion that in view of the incompleteness of the preliminary investigation and its onesided direction, the number of acquittals increased. This has led to the fact that the judicial investigation has become the most "refractory" structure.

In 1869 , a special commission was created to consider problematic issues of the functioning of the apparatus of judicial investigators. In conclusion, she ruled that one of the reasons for the abnormally unsatisfactory work of investigators is the lack of a competently structured police search for the perpetrators, which, by its nature, should closely interact with the preliminary investigation bodies at the stage of pre-trial proceedings (Azarov, 2012, p. 112)

Nevertheless, the reform gave its results, the main of which we consider the establishment of the bodies of the judicial investigation. But the institution of judicial investigation existed for a relatively short period of time and was gradually lost with the onset of 1917 and the coming to power of the Bolsheviks. Gradually, the judicial investigation passed from the judiciary to the executive branch.

So, in clause 3 of the Decree of the Council of People's Commissars of the RSFSR "On Court No. 1" dated December 24, 1917, it was said that the preliminary investigation was assigned to local judges alone until the entire procedure of legal proceedings was transformed. 
Clause 4 of the Decree of the NCJ of the RSFSR of December 15, 1917: "On the measures of imprisonment of detainees and on the establishment of commissions of inquiry in prisons to check the correctness and legality of arrest" contains a provision on the creation of temporary commissions of inquiry in prisons (of three people) to check the legality and validity of arrests, by agreement of the Petrograd Soviet with the district Soviets of Workers and Soldiers Deputies.

Published on December 19, 1917, the NCJ Instruction "On the revolutionary tribunal, its composition, the cases subject to its jurisdiction, the penalties imposed by it and the procedure for conducting its sessions" and the Decree of the Council of People's Commissars of the RSFSR of January 28, 1918 “On the Revolutionary Press Tribunal” only consolidated the existing regulation. Thus, in order to make a decision on the arrest, search, seizure and release of those arrested, it was necessary to assemble a collegium of three persons. A sole decision could be made only in a case that could not be delayed, but at the same time, such a measure was approved by the commission within 12 hours. Thus, this indicates that there is no need for court control over the legality and justification of the application of the above measures.

The Regulation on the People's Court of the RSFSR, approved by the Decree of the All-Russian Central Executive Committee of October 21, 1920, provided for the establishment of a new body - People's Investigators, under the jurisdiction of the Council of People's Judges. People's investigators were elected by the Provincial Executive Committees of the Soviets and acted within their area.

Investigators were also appointed for the most important cases, which were under the jurisdiction of the departments of justice and the People's Commissariat of Justice. According to Art. 32 of the Regulations, the people's investigator could start the preliminary investigation on the basis of applications from citizens, according to the police, officials and institutions, by order of the People's Court and at his own discretion.

The investigator's demands were obligatory both for the police and for other bodies and institutions. There is a growing role of investigative bodies and an increase in their procedural independence.

However, already in May 1922, with the adoption of the Regulations on Prosecutor's Supervision, approved by the All-Russian Central Executive Committee, supervision over the activities of the investigative bodies was entrusted to the Prosecutor's Office.

According to Art. 121 of the Code of Criminal Procedure of 1922, supervision over the production of the preliminary investigation is carried out by the prosecutor, who also has the right to familiarize himself with the acts of the preliminary investigation and give instructions to the 
investigator, which are binding. At the same time, the prosecutor's office for this period was not the only controlling body for the investigator. The latter also remained subordinate to the court. So, according to Art. 216 of the Code of Criminal Procedure of 1922, all interested persons, as well as parties, witnesses, experts, translators, attesting witnesses, guarantors, pledgers for the accused could bring complaints about the actions of the investigator that violated their rights. Such complaints are considered by the court at which the investigator is a member.

During this period, a scientific discussion arises among scientistsproceduralists, associated with the choice of the optimal model for the development of the investigative apparatus and with the consolidation of the role of the prosecutor in it. There was a lot of controversy about the latter. So, A. Y. Vyshinsky supported the complete removal of control and supervisory powers from the court and the assignment of such powers to the prosecutor. In opposition to this point of view, the first chairman of the Supreme Court of the RSFSR P. Y. Knock. He believed that the control and supervisory functions should be fully retained for the court (Tsvetkov, 2015).

In September 1928, new changes took place. The resolution of the All-Russian Central Executive Committee and the Council of People's Commissars of the RSFSR "On Amendments to the Regulations on the Judicial System of the RSFSR" secured the transfer of the investigative apparatus to the full subordination of the prosecutor's office.

The essence of such an investigation was that the prosecutor began to direct the investigation, giving binding instructions, authorizing many actions and decisions of the investigator, exercising supervision over him. A paradoxical situation was created: the investigator was largely the executor of the will of the prosecutor during the preliminary investigation, and the prosecutor practically began to exercise supervision over himself (Manova, 2015).

Y. A. Tsvetkov claims that such a prosecutor's model for carrying out a preliminary investigation existed until 1938. Such a tendency:

To the destruction of the prosecutor's monopoly on the preliminary investigation was laid in its very conceptual basis, which did not recognize the independent legal nature of the investigation. In the future, such a concept will present us with the fact that every department that has at least some kind of police powers will seek to "pinch off" a "piece" of investigative functions for itself (Tsvetkov, 2015, p. 33).

Subsequently, in connection with the formation of an investigative unit based on the NKVD of the USSR, which, in turn, was reorganized into an investigative part of the main department of state security and an investigative part of the main economic department, this model was lost. 
It is worth noting that such a complete concentration in one hand of all the investigative work had negative aspects, for example, in the form of an overload of investigators.

But this situation, on the other hand, aroused a growing interest in the bodies of inquiry. In this regard, in 1940-1950, the police created their own investigative bodies, which were no longer directly subordinate to the prosecutor's office, but to the investigation department of the Main Police Department of the USSR Ministry of Internal Affairs. But still, so far, they did not have the legal right to carry out the preliminary investigation in full and carried out only individual orders of the investigators.

The adoption of the Fundamentals of Criminal Procedure of the USSR in 1958 and the Code of Criminal Procedure of the RSFSR in 1960 served as the beginning of a global discussion about the departmental affiliation of the preliminary investigation. But, as before, at the legislative level, which was enshrined in Art. 25 of the Code of Criminal Procedure of the RSFSR, the right of procedural supervision over the prosecution authorities was retained.

By decree of the Presidium of the Supreme Soviet of the USSR No. 1237-VI of April 6, 1963 "On granting the right to conduct a preliminary investigation to public order protection bodies", the right to conduct a preliminary investigation was transferred to the Ministry of Public Order Protection of the USSR (USSR Ministry of Internal Affairs), which marked the beginning of the official work of the investigative bodies of internal affairs.

The right to conduct a preliminary investigation was vested in investigators of public order protection agencies. Their work was supervised by the heads of the investigative bodies. Thus, during the first half of the 6os, the powers of the head of the investigative body, who exercised control functions over the activities of the internal affairs officers conducting the inquiry and investigation, were formalized. But so far, these powers have been reflected only in departmental regulations.

Clause 6 of Art. 34 of the Code of Criminal Procedure of the RSFSR contained a definition of the concept of the head of the investigation department, which came to be understood as the head of the investigation department, department, department of public order, state security and his deputies, acting within their competence.

So, now the head of the investigative body performed the following functions: exercising control over the activities of the investigator in solving and investigating crimes, checking criminal cases, giving binding instructions on the progress of the investigation, seizing the case and transferring it to another investigator, entrusting the investigation to several investigators, as well as personally took part in the investigation. 
Thus, in accordance with the Code of Criminal Procedure of the RSFSR, the head of the investigation department was endowed with a very small range of organizational powers. In the academic environment of the $60 \mathrm{~s}$ and 70s a discussion broke out about the procedural position of the head of the investigation department. Some suggested expanding the powers of the head of the investigation department, transferring to him certain powers of the prosecutor, for example, the right to remove the investigator from the investigation, cancel his decisions, allow challenges and some others (Urakov, 1964, p. 16).

Of course, there were also opponents of such ideas who said that such a comprehensive empowerment of the head of the investigation department would oppress the procedural independence of the investigator. It was also suggested that such a transfer of powers from one "hand to another" would not entail any positive changes for the investigation but would only change the name in the form of control (Chistyakova, 1964).

This issue has not lost its relevance in the course of the judicial and legal reform of the late XX century. In the course of the development of the draft law of the new Code of Criminal Procedure of the Russian Federation, the discussion did not subside, but, on the contrary, only became more acute. So, during this period, in addition to the already existing positions, ideas were put forward to eliminate the procedural figure of the head of the investigative body, as well as to significantly reduce the functions of the head of the investigative department in order to ensure the procedural independence of the investigator. As a result, in some bills the figure of the head of the investigation department was deprived of procedural status, and his powers were either left unchanged or significantly reduced.

In the current Criminal Procedure Code of the Russian Federation in 2001, the figure of the head of the investigation department was retained, and the scope of his powers was somewhat expanded. Thus, for the first time in legislation, the right of the head of the investigation department to cancel the unfounded decisions of the investigator to suspend the criminal case was enshrined.

The Code retained the following powers for the head of the investigation department: he, as before, could entrust the investigation to one or several investigators, he had the right to accept a criminal case for his own proceedings and conduct an investigation independently in full, using all the powers of the investigator. The head of the investigation department had organizational powers, supervised the work of the investigator, checked the materials of the criminal case, could give binding instructions on the direction of the investigation, the application of preventive measures, and the qualification of the crime. 
During this period, the question arises of a clear delineation of the functions of the prosecutor and the head of the investigation department, since the border between the prosecutor's control and departmental control began to blur (Manova, 2015). Particularly relevant is the question of expanding the adversarial principle in the stages of pre-trial proceedings in a criminal case, while the most acute, as V. V. Pushkarev correctly notes, there is a problem of correlation of powers of the investigator and the head of the investigative body, on the one hand, and the prosecutor, on the other, at the end of the preliminary investigation with the preparation of the indictment (Pushkarev et al., 2021).

The next stage of transformations of the institution of departmental control is associated with the establishment of the Investigative Committee under the Prosecutor's Office of Russia in 2007. At the same time, significant changes were made to the Criminal Procedure Code of the Russian Federation concerning the head of the investigation department. From that moment on, he began to be called the head of the investigative body. Its powers have also been significantly expanded. Practically all the power and administrative powers of the prosecutor regarding control over the course of the preliminary investigation have been added to the functions already existing.

After the 2007 reform, the legal literature again started talking about the need to return to the prosecutor some of the control and supervisory powers in the field of preliminary investigation. For example, it was proposed to return the authority to check the materials of the criminal case, cancel the illegal and unjustified decisions of the investigator, give binding instructions to the investigator about the direction of the investigation and the performance of certain investigative actions.

In addition, suggestions were made about the need to impute to the prosecutor the right to initiate a criminal case, conduct an investigation himself, entrust it to an inquirer or investigator, and also stop criminal prosecution (Popova, 2015, p. 201).

Federal Law No. 403-FZ of 28.12.2010 "On the Investigative Committee of the Russian Federation" separated the Investigative Committee from the Prosecutor's Office, which also entailed the need to amend the Code of Criminal Procedure of the Russian Federation.

So, part 2 of Art. 37 of the Code of Criminal Procedure of the Russian Federation was supplemented with clause 5.1, which implied the right of the prosecutor to demand and verify the legality and validity of the decisions of the investigator or the head of the investigative body to refuse to initiate, suspend or terminate a criminal case, as well as the right to subsequently make decisions on them. In accordance with paragraph 12 of Art. 37 of the Code of Criminal Procedure of the Russian Federation, the prosecutor 
had the right to seize the criminal case or inspection materials from the investigator and transfer them to another body of preliminary investigation or to the Investigative Committee of Russia. According to this law, the competence of the head of the investigative body began to include the right to cancel illegal or unreasonable decisions of the head, investigator of another body of preliminary investigation on criminal cases pending under the jurisdiction of a subordinate investigative body.

\section{Conclusions}

In conclusion, the authors substantiated the conclusion that the negative impact of the comprehensive administrative function of the head of the investigative body is often expressed in excessive suppression of the procedural independence of the investigator by a series of instructions on the direction of the investigation, the application of preventive measures, or the qualification of the accusation. Of course, this is one of the modern multifaceted problems of the institution of departmental procedural control over the procedural activities of an investigator in pre-trial criminal proceedings.

In the future, we see a steady trend of expanding the procedural status of the head of the investigative body. Art. 39 of the Code of Criminal Procedure of the Russian Federation continues to be supplemented by editions of powers, thus, endowing the head of the investigative body not so much with organizational functions as, for the most part, with power and administrative functions.

\section{Bibliographic References $^{6}$}

AZAROV, Vladimir Alexandrovich. 2012. The function of preliminary investigation in the history, theory and practice of the criminal procedure in Russia: monograph. Legal literature. Omsk, Russia.

CHISTYAKOVA, V.S. 1964. Bodies of preliminary investigation of crimes and the delimitation of competence between them: author. diss. Cand. jurid. sciences. Moscow, Russia.

DANEVSKY, V.P. 1985. Our preliminary investigation, its shortcomings and reforms. Quickly, Moscow, Russia.

6 Some cited sources only have the initial of the name of the author or authors because it was impossible to locate their full name as stable the standard of this journal. 
KOLOKOLOV, N.A. 2009. "The latest novels of the Criminal Procedure Code of the Russian Federation: the balance of the prosecution power is stabilizing” In: Criminal proceedings. No. 2, pp. 28-33.

MAMONTOV, A.G. 1984. Formation of the institution of preliminary investigation in the framework of the judicial reform of 1864: Monograph. Legal Press. Moscow, Russia.

MANOVA, N.S. 2015. "Formation of the institution of departmental management of the activities of an investigator in the Russian criminal process (statutes of criminal proceedings and current legislation)" In: Vestnik VSU, Ser. 5. Jurisprudence. Vol. 1, No, pp. 26-36.

POPOVA, T.Yu. 2015. "Changing the balance of powers of the prosecutor and the head of the investigative body", In: Bulletin of the Kemerovo State University. Vol. 2, No. 62, 201-205.

PUSHKAREV, Viktor Victorovich; GAEVOY, Alexander Ivanovich; KOLCHURIN, Andrei Gennadievich; BUKHAROV, Nikolay Nikolaevich; PCHOLOVSKY, Nikolay Kazimirovich. 2021. "Ensuring the principle of adversarial parties by the investigator at the end of the criminal prosecution", In: Laplage em Revista (International). Vol.7, No. Extra A, pp. 304-310.

TARASOV, A.V. 2001. Institute of forensic investigators for reforms in the middle of the XIX century (historical and legal analysis): author. diss. Cand. jurid. sciences. Saint Petersburg, Russia.

TSVETKOV, Yu. A. 2015. "Historical stages in the development of the bodies of preliminary investigation in Russia” In: History of state and law. No. 3, pp. 33-37.

URAKOV, L.I. 1964. "On the procedural status of employees of the investigative departments of public order protection bodies" In: Socialist legality. No. 7, 16-20. 

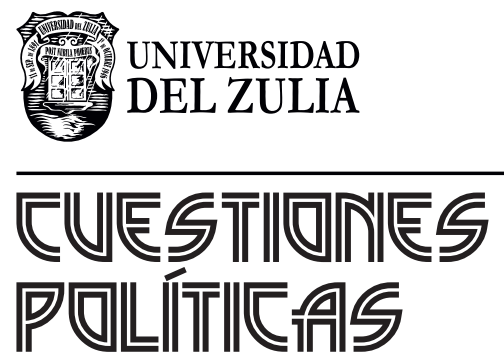

Vol. 39 N $^{\circ} 71$

Esta revista fue editada en formato digital y publicada en diciembre de 2021, por el Fondo Editorial Serbiluz, Universidad del Zulia. Maracaibo-Venezuela 